\title{
A Study to Evaluate the Effectiveness of Laughter Yoga Exercises on Stress Reduction due to Online Classes among Ist Year B.Sc. Nursing Students in Mother Teresa College of Nursing, Pudukkottai
}

\author{
R. Geetha \\ Vice Principal, Mother Teresa College of Nursing Pudukkottai -622102
}

\begin{abstract}
A quantitative study was conducted among Ist year B.sc nursing students of Mother Teresa College of nursing, Pudukkottai. The main objective of this study is to assess and compare the pre-test and post-test level of stress among I st year B.sc nursing students and to evaluate the effectiveness of laughter yoga exercise on the level of stress among Ist year B.sc nursing students. Pre experimental design with Purposive sampling technique was used.50 samples agreed to participate in this study. The data was used by structured questionnaire scheduled. Data was used by descriptive and inferential statistics. The mean score of pre-test level of stress is 8.14 and mean score of posttest level of stress is 17.14. The enhancement of knowledge in mean score and SD which the effectiveness of laughter yoga exercises. The analysis depicted that there is reduction of stress level due to online classes among I st year B.sc nursing students which indicates the effectiveness of laughter yoga exercise.
\end{abstract}

Keyword: Assess, effectiveness, Laughter yoga exercises, Stress reduction, BSc nursing students

\section{INTRODUCTION}

Laughter is a natural behavior which is executed by the brain. It reduces fear and anger at least for a moment and evokes the senses of both control and hope. In the year of 1995 Laughter yoga was invented by a Hindi physician named Madan Kataria. It combines the standard yoga breathing exercises with laughing exercises including a variety of fun sports too (Pezeshki, 2014).
Kataria (2016) stated that when someone pretends to laugh or be happy, the body produces chemicals that induce a state of happiness. If the body feels happiness, automatically mind will follow a happy state. The merits of laughter yoga are that it is easy to prescribe and does not cause adverse effects with respect to allergies, dose, and side effects.

Laughter Yoga has the ability to change the mood state instantaneously. A laughter is a very good therapy for relaxation, which helps to reduce the tension, keeps the person calm that alleviates both physical and mental pain. Laughter makes the person to feel comfortable, energetic and tension free.

Laughter yoga lowers the blood pressure, relieve stress, increase muscle flexion and boost the immune system by raising the level of infection fighting $\mathrm{T}$ cells, disease fighting proteins (gamma interferon) and beta cells. It also triggers the release of endorphins (body's natural pain killer) and produces a general sense of wellbeing. The positive psychological effect of laughter yoga includes mental alertness, increase in concentration, cooperation, creativity and self-confidence plus better ability to cope with stress (Prakasan, 2016).

Nursing students had experience in stress at different levels due to many of the reasons such as life style, health, academic performance, competition, choice of career, new life environment relations with peer group, and expectations of parents. 
Laughter is essential for your health. Laughter boosts the immune system. Laughter stimulate to release of endorphins, the body's natural feel-good chemicals. Laughter relaxes the whole body Laughter protects the heart. Laughter burns calories. .Laughter lightens anger's heavy load. Laughter may even help you to live longer.

Steps laughing yoga exercise. Step 1: Clapping and Warming-up Exercises: Step. 2: Deep Breathing Exercises Laughter exercises. Step 3: Childlike Playfulness: 4: Laughter Exercises. They are three types: Yogic Laughter Exercises, Playful Laughter Exercises and Value-based Laughter Exercises.

Leeberk (2014) revealed that Laughter Yoga can have a variety of psychological and physiological health benefits, including improved coping skills, enhanced mood and feelings of well-being, decreased discomfort, and a higher pain tolerance as well as reduced neuro immune and stress markers.

Christie and Moore (2014) revealed that humor might be an excellent clinical intervention. The researcher reported that there are many benefits of laughter Yoga on depression, tension, anxiety, rage and insomnia. It is suggested that energetic laughing exercise and the resulting relaxing of muscles stimulates circulation, improves respiration, increases production of pain inhibitors, decreases stress related hormones and enhances the immune system.

Stress not only happens at workplace but students are subjected to different kinds of stressors, such as the presence of the academics with an obligation to succeed, an uncertain future and difficulties of integrating into the system. The students have so many different problems such as physical, social, emotional, and family problems which might affect their learning ability and academic performance. It is important for each and every individual to enhance different strategies in order to manage stressful situations.
In worldwide 66 million suffer from depression, 24 million affected from alcohol related problems, 1 million people commit suicide each year 1 in 4 people is affected by mental or neurological disorders at some point of his or her life. This means such disorders are the fourth leading cause of ill health and disability worldwide. Mental disorders are expected to rank 2 nd by 2020 , behind ischemic heart disease (WHO)

As of 30 November 2020, the pandemic had caused nearly 1.46 million deaths of 63.1 million confirmed cases, and put people under tremendous psychological pressure. Stress is not only a affect daily life activities, but also create additional delays in academic activities, which are positively correlated with stress and students' level of anxiety.

\section{Objectives}

* To assess and compare the pre-test and post-test level of stress among I st year B.sc nursing students

* To evaluate the effectiveness of laughter yoga exercise on the level of stress among I st year B.sc nursing students

* To find out the association between the levels of stress among I st year B.sc nursing students with selected demographic variables.

\section{HYPOTHESIS}

H1: There is a significant difference between pre-test and post-test level of Stress among I st year B.sc nursing students

H2: There is a significant reduction in the level of stress among I st year B.sc nursing students

H3: There is a significant association between the levels of stress among I st year B.sc nursing students with selected demographic variables.

\section{ASSUMPTION}

* Stressors life not only affects I st year B.sc nursing student's physical health but also their mental, social relationships and academics performance. 
* Laughter yoga exercise can promote the mental health and improve academic achievement and provide clinical services in the hospital by I st year B.sc nursing students.

\section{RESEARCH METHODOLOGY}

Pre experimental research design was adopted for this study. The study was conducted in mother Teresa College of nursing at Pudukkottai, Tamil Nadu. 50 adolescent girls were recruited for this study through the purposive sampling technique. The data were collected after obtaining the institutional ethical clearance and formal administrative permission. Informed consent from the subjects was obtained and the confidentiality has been assured.

A structured questionnaire was used to evaluate the level of stress of I st year B.sc nursing students. The questionnaire was translated in to the vernacular language: Tamil, the appropriateness of the translation was verified by back translation. The reliability of the questionnaire was established using test retest method $(r=0.9)$. There were 30 multiple choice questions related to general information on stress,
Consequences and its prevention. Each correct response had been given the score of one. In pre-test $66 \%$ of the I st year B.sc nursing students had moderate stress, $24 \%$ of them had severe stress and $10 \%$ of the I st year B.sc nursing students had mild stress where as in the post-test about $56 \%$ of the I st year B.sc nursing students had only mild stress, $36 \%$ of them had moderate stress and $8 \%$ I st year B.sc nursing students had severe stress

Pre-test on assessment of knowledge were conducted by using the structured questionnaire. Time taken by the Ist year B.sc nursing students to complete the knowledge questionnaire was approximately 30 minutes. After the pre-test, the students were divided in to five groups of having 10 subjects in each. Laughter yoga exercise about stress was administered for 30 minutes for each group. The post-test was conducted after fourteen days of intervention.

\begin{tabular}{|c|c|c|c|}
\hline GROUPS & $\begin{array}{l}\text { Pre } \\
\text { test }\end{array}$ & $\begin{array}{c}\text { Laughter yoga exercise } \\
\text { intervention }\end{array}$ & Post-test. \\
\hline $\begin{array}{l}\text { Experimental } \\
\text { group }\end{array}$ & O1 & $\mathrm{X}$ & $\mathrm{O} 2$ \\
\hline
\end{tabular}

\section{RESULTS AND DISCUSSION}

Table 1: Distribution of demographic variable $\quad \mathrm{N}=\mathbf{5 0}$

\begin{tabular}{|c|c|c|c|}
\hline \multirow[t]{2}{*}{ S.No } & \multirow[t]{2}{*}{ Demographic variables } & \multicolumn{2}{|c|}{ Experimental Group } \\
\hline & & Frequency (n) & Percentage (\%) \\
\hline \multirow[t]{5}{*}{1.} & Age in years & & \\
\hline & 17 years & 30 & $60 \%$ \\
\hline & 18 years & 16 & $32 \%$ \\
\hline & 19 years & 3 & $6 \%$ \\
\hline & 20 years & 1 & $2 \%$ \\
\hline \multirow[t]{5}{*}{2.} & Mark scored in higher secondary & & \\
\hline & $<50 \%$ & 6 & $12 \%$ \\
\hline & $50-60 \%$ & 16 & $32 \%$ \\
\hline & $61 \%-75 \%$ & 24 & $48 \%$ \\
\hline & $>76 \%$ & 4 & $8 \%$ \\
\hline \multirow[t]{3}{*}{3.} & Medium of instructions & & \\
\hline & Tamil & 38 & $76 \%$ \\
\hline & English & 12 & $24 \%$ \\
\hline \multirow[t]{5}{*}{4.} & Educational background of the father & & \\
\hline & Primary level & 20 & $40 \%$ \\
\hline & High school / Higher secondary level & 20 & $40 \%$ \\
\hline & Diploma or degree level & 6 & $12 \%$ \\
\hline & Post graduate level & 4 & $8 \%$ \\
\hline \multirow[t]{5}{*}{5.} & Educational background of the mother & & \\
\hline & Primary level & 18 & $36 \%$ \\
\hline & High school level /Higher secondary level & 26 & $52 \%$ \\
\hline & Diploma or degree & 4 & $8 \%$ \\
\hline & Post graduate level & 2 & $4 \%$ \\
\hline
\end{tabular}


R.Geetha. A study to evaluate the effectiveness of laughter yoga exercises on stress reduction due to online classes among Ist year Bsc nursing students in Mother Teresa College of Nursing, Pudukkottai

\begin{tabular}{|c|c|c|c|}
\hline \multicolumn{4}{|c|}{ Table no. 1 continued........ } \\
\hline 6 & Occupation of the head of the family & & \\
\hline & Coolie & 30 & $60 \%$ \\
\hline & Private & 8 & $16 \%$ \\
\hline & Government & 6 & $12 \%$ \\
\hline & Business & 4 & $08 \%$ \\
\hline & Professionals & 2 & $04 \%$ \\
\hline \multirow[t]{4}{*}{7.} & Place of residence & & \\
\hline & Rural & 36 & $72 \%$ \\
\hline & Urban & 12 & $24 \%$ \\
\hline & Semi urban & 2 & $4 \%$ \\
\hline \multirow[t]{5}{*}{8.} & Family income per month & & \\
\hline & $3000-5000$ & 28 & $56 \%$ \\
\hline & $5001-10000$ & 16 & $32 \%$ \\
\hline & $10001-20000$ & 5 & $10 \%$ \\
\hline & Above 20001 & 1 & $2 \%$ \\
\hline \multirow[t]{4}{*}{9.} & Religion & 18 & $36 \%$ \\
\hline & Hindu & 36 & $72 \%$ \\
\hline & Muslims & 12 & $24 \%$ \\
\hline & Christians & 4 & $8 \%$ \\
\hline \multirow[t]{4}{*}{10.} & No of sibling & & \\
\hline & One & 28 & $56 \%$ \\
\hline & Two & 14 & $28 \%$ \\
\hline & More than two & 8 & $16 \%$ \\
\hline \multirow[t]{5}{*}{11.} & Type of family & & \\
\hline & Nuclear & 30 & $60 \%$ \\
\hline & Joint & 10 & $20 \%$ \\
\hline & Extended & 4 & $8 \%$ \\
\hline & Separated & 6 & $12 \%$ \\
\hline \multirow[t]{4}{*}{12.} & Type of sociability & & \\
\hline & Not mingle with others & 12 & $24 \%$ \\
\hline & Mingle with selected people & 26 & $52 \%$ \\
\hline & Mingle with everyone & 12 & $24 \%$ \\
\hline \multirow[t]{5}{*}{13.} & Hobbies & & \\
\hline & Watching Television & 21 & $41 \%$ \\
\hline & Listening to music & 10 & $20 \%$ \\
\hline & Chatting with friend & 7 & $14 \%$ \\
\hline & Playing video game & 12 & $24 \%$ \\
\hline \multirow[t]{3}{*}{14.} & Previous knowledge about online classes & & \\
\hline & Yes & 22 & $44 \%$ \\
\hline & No & 28 & $56 \%$ \\
\hline
\end{tabular}

Majority of the I st year B.sc nursing students $(60 \%)$ were in the age group of 17 years and most of them $(48 \%)$ have scored more than $60 \%$ of marks. $76 \%$ of them studied in Tamil medium. Majority of parents (40\% of father and $52 \%$ of mother) had studied higher secondary education. $60 \%$ of the fathers are working as a coolie. Most of the Ist year B.sc nursing students $(60 \%)$ were belonged to nuclear family. Regarding residence, $72 \%$ of them were from rural area and $24 \%$ of them from urban area. Nearly $56 \%$ of them had family income Rs.3000-RS.5000 per month. Majority of them (70\%) belongs to Hindu religion. $56 \%$ of the students have only one sibling. Majority of them $(52 \%)$ were mingling with only selected people. $52 \%$ of them did not have previous knowledge about online classes

The above table reveals that Majority of the I st year B.sc nursing students $(60 \%)$ were in the age group of 17 years and most of them $(48 \%)$ have scored more than $60 \%$ of marks. $76 \%$ of them studied in Tamil medium. Majority of parents (40\% of father and $52 \%$ of mother) had undergone higher secondary education. $60 \%$ of the fathers are working as a coolie. Most of the Ist year B.sc nursing students $(60 \%)$ were belonged to nuclear family. Majority of them $(70 \%)$ belongs to Hindu religion. $56 \%$ of the students have only one sibling. Majority of them (52\%) were mingling with only selected people. $52 \%$ of them did not have previous knowledge about online classes. 
R.Geetha. A study to evaluate the effectiveness of laughter yoga exercises on stress reduction due to online classes among Ist year Bsc nursing students in Mother Teresa College of Nursing, Pudukkottai

Table 2: Distribution of I st year B.sc nursing students according to the Level of stress due to online classes before and after laughter Yoga Exercise

\begin{tabular}{|l|c|c|c|c|}
\hline \multirow{2}{*}{ Levels of Stress } & \multicolumn{2}{|c|}{ PRE TEST } & \multicolumn{2}{c|}{ POST TEST } \\
\cline { 2 - 5 } & $\begin{array}{c}\text { Frequency } \\
(\mathbf{n})\end{array}$ & $\begin{array}{c}\text { Percentage } \\
(\mathbf{\%})\end{array}$ & $\begin{array}{c}\text { Frequency } \\
(\mathbf{n})\end{array}$ & $\begin{array}{c}\text { Percentage } \\
(\mathbf{\%})\end{array}$ \\
\hline Normal & 00 & 00 & 00 & 00 \\
\hline Mild stress & 05 & 10 & 28 & 56 \\
\hline Moderate stress & 33 & 66 & 18 & 36 \\
\hline Severe stress & 10 & 20 & 3 & 06 \\
\hline Extremely stress & 2 & 4 & 1 & 02 \\
\hline \multicolumn{1}{|c|}{ Total } & $\mathbf{5 0}$ & $\mathbf{1 0 0}$ & $\mathbf{5 0}$ & $\mathbf{1 0 0}$ \\
\hline
\end{tabular}

The above table revealed that during pre-test, $10 \%$ of the I st year B.sc nursing students had mild stress, $66 \%$ of the I st year B.sc nursing students had moderate stress, $20 \%$ of them had severe stress and $6 \%$ of them had extremely stress where as in the post-test about $56 \%$ of the I st year B.sc nursing students had only mild stress, $36 \%$ of them had moderate stress, $6 \%$ of the I st year B.sc nursing students had severe stress and $2 \%$ of them had extremely stress.

Table 2: Effectiveness of laughter yoga exercise on online classes Related to stress among I st year B.sc nursing students

\begin{tabular}{|l|c|c|c|c|c|c|c|c|}
\hline \multirow{2}{*}{ S.no } & Variables & \multirow{2}{*}{$\begin{array}{l}\text { Total } \\
\text { score }\end{array}$} & \multicolumn{2}{|c|}{ Pre test } & \multicolumn{2}{|c|}{ Post test } & \multirow{2}{*}{$\begin{array}{c}\text { Mean } \\
\text { difference }\end{array}$} & $\begin{array}{c}\text { Paired } \\
\text { t test }\end{array}$ \\
\cline { 4 - 6 } & & & Mean & SD & Mean & SD & & \\
\hline 1. & Level of stress & 30 & 8.14 & 2.07 & 17.14 & 2.02 & 9.00 & 21.9 \\
\hline
\end{tabular}

Further, mean post-test level of knowledge scores among the I st year B.sc nursing students $(17.14+2.07)$ was significantly higher $(\mathrm{P}<0.05)$ than mean pre-test knowledge score $(8.14+2.02)$. The statistically significant association $(\mathrm{P}<0.05)$ was found between knowledge and hobbies.

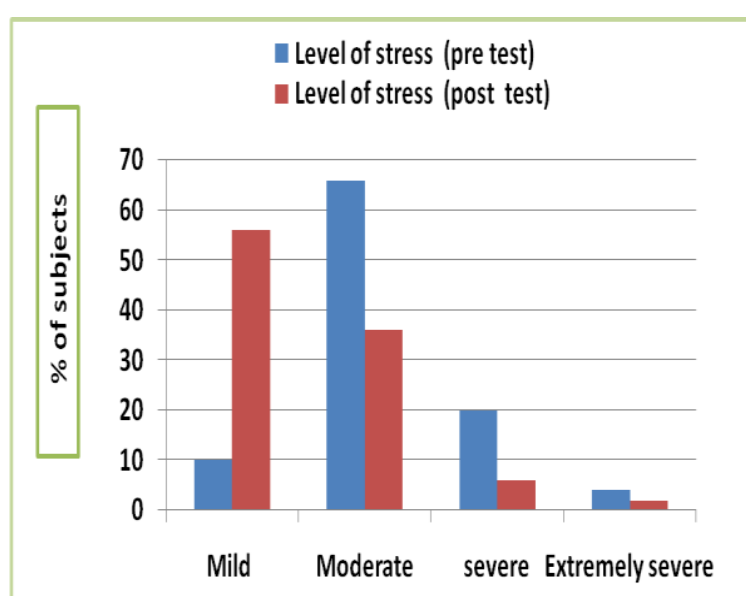

Figure 3: Level of stress due to online classes among I st year B.sc nursing students during pre and post test

The above figure revealed that during pre-test, $10 \%$ of the I st year B.sc nursing students had mild stress, $66 \%$ of the I st year B.sc nursing students had moderate stress, $20 \%$ of them had severe stress and $6 \%$ of them had extremely stress where as in the post-test about $56 \%$ of the I st year B.sc nursing students had only mild stress, $36 \%$ of them had moderate stress, $6 \%$ of the I st year B.sc nursing students had severe stress and $2 \%$ of them had extremely stress

The present study revealed that laughter yoga exercise regarding stress is significantly effective $(\mathrm{P}<0.05)$ in improving the knowledge (pre-test mean $(8.14+2.07)$ vs post-test mean $(17.14+2.02)$ of I st year B.sc nursing students regarding stress. They found a significant $(\mathrm{P}<0.05)$ improvement in the knowledge of the subjects regarding stress after the laughter yoga exercise.

The findings of this study have significant implications for the nursing practice. The nurses involved in child health care should actively participate in planning and implementation of strategies to reduce the stress. Laughter yoga exercise can be used as a tool to teach I st year B.sc nursing students on various topics related to the stress.

\section{CONCLUSION}

This study revealed that Laughter yoga exercise regarding stress among Ist year B.sc nursing students was very effective. This confirms that Laughter yoga exercise as a tool could be utilized 
effectively to create awareness on various topics.

The study concluded that I st year B.sc nursing students had stress at different levels. The difference in the level of stress by the paired ' $t$ ' value 21.9 which was found significant at $\mathrm{p}<0.05$ with the table value of 2.02 shows the effectiveness Laughter yoga exercise of on stress level among the Ist year B.sc nursing students

\section{Source of Funding: Self}

\section{Conflict of Interest: Nil}

\section{Ethical Approval: Approved}

\section{REFERENCE}

1. Benson, A. Labor market trends among registered nurses 2008- 2011. Policy, Politics \& Nursing Practice, 13(4), (2013). 205-213.

2. Decker, J. L. \& Shellenbarger, T. Strategies for nursing faculty to promote a healthy work environment for nursing students Teaching and Learning in Nursing, (7), (2012).56-61.

3. H. Hasan, T.F. Hasan. Laugh yourself into a healthier person: a cross cultural analysis of the effects of varying levels of laughter on health. International journal of medical sciences.(2009);6:200

4. Li, H-C., Wang, L.S., Y-H., Lin, \& Lee, I. The effect of a peer-mentoring strategy on student nurse stress reduction in clinical practice. International Nursing Review,58, (2011). 203-210.

5. Lynden, G. Helping students belong. The Forum of Fargo-Moorhead.(2014),pp.1A, $4 \mathrm{~A}$

6. Mahmoud, J.S.R., Staten, R. T., Hall, L.A., \& Lennie, T. A. The relationship among young college students' depression, anxiety, stress, demographics, life satisfaction, and coping styles. Issues in Mental Health Nursing, (2012), 149-156.

7. Melincavage, S. M. Student nurses' experiences of anxiety in the clinical setting. Nurse Education Today, (2011), 785-789.

8. Mancino, D. Recalculating: The "nursing shortage" needs new direction. Dean's Notes, 34(3), (2013). 1-3.

9. R.Bagheri. The study of the effect of laughter therapy on group cataract on the reduction of occupational stress among female teachers of elementary school in District 13 of Tehran. In Faculty of Educational Sciences and Psychology (2011)

10. Z.Badr. The effect of laughter therapy on general health and stress among nurses working in Yasuj hospitals. In Faculty of Humanities, Department of Psychology (Yasuj Branch: Islamic Azad University)

How to cite this article: R. Geetha. A study to evaluate the effectiveness of laughter yoga exercises on stress reduction due to online classes among Ist year B.Sc. nursing students in Mother Teresa College of Nursing, Pudukkottai. International Journal of Science \& Healthcare Research. 2021; 6(2): 168-173. DOI: https://doi.org/10.52403/ijshr.20210430 